\title{
Management Education in Chile: From Politics of Pragmatism to (Im)Possibilities of Resistance*
}

\author{
Educación en Negocios en Chile: desde la política del \\ pragmatismo hacia la resistencia (im)posible
}

Recibido: marzo 4 de 2013 | Revisado: julio 1 de 2013 | Aceptado: agosto 15 de 2013

\author{
Marcela Mandiola CotroneO ** \\ Universidad Alberto Hurtado, Chile
}

Doi: 10.11144/Javeriana.UPSY12-4.meic

Para citar este artículo: Mandiola, M. (2013). Management education in Chile: From politics of pragmatism to (im)possibilities of resistance. Universitas Psychologica, 12(4), 1085-1098. Doi: 10.11144/Javeriana.UPSY12-4.meic

* Este artículo se basa en el proyecto Fondecyt No 11121353.

** Universidad Alberto Hurtado, Chile. PhD. ResearcherID: M-5326-2013. Faculty of Economics and Business.E-mail: mmandiol@uahurtado.cl

\footnotetext{
A B S T R A C T

Having in mind a personal question about the status of affairs within Chilean management educational practices and its critical possibilities, I engaged in the exploration of its historical and social conditions of (im) possibilities against the backdrop of Critical Management Studies field, Critical Management Education stream as well as the traditional Latin American radical philosophy. To make sense about these themes and debates I informed my research by the theoretical developments of Laclau and Mouffe's Discourse Theory, which played the role of both, general framework and methodological inspiration.

Key words authors

CMS, CME, liberation, mainstream management, Latin America.

Key words plus

Critical Social Psychology, Qualitative Research, Discourse.

\section{RESUMEN}

Teniendo en consideración cuestionamientos personales acerca del estado del arte en la práctica de educación en negocios en Chile y sus posibles críticas, realicé una exploración de sus condiciones históricas y sociales de (im)posibilidad. Dicho análisis fue inspirado por el campo de los Estudios Críticos de la Gestión (CMS), la Educación en Negocios Crítica (CME) y la tradición filosófica latinoamericana radical. Estos temas han sido movilizados desde el desarrollo teórico de Laclau y Mouffe, el cual ha jugado ambos roles: el de marco teórico e inspiración metodológica.

Palabras claves autores

CMS, CME, liberación, management tradicional, América Latina.

Palabras clave descriptores

Psicología social crítica, investigación cualitativa, discurso.
} 


\section{Introduction}

This paper is divided into four sections which, in turn, are the main contributions of my research as a whole. The first section is devoted to Critical Management Studies and Critical Management Education as current articulators of dissent. As we have seen in the Northen academic management literature, both streams have developed a relevant effort in denouncing the narrowness of traditional management as a field and the negative and oppressive consequences of its practice. Although I recognize its contribution to the field, were their insights wich really motivated my own research, I attempted to challenge their achivements problematizing their lack os public contestation beyond academic proups as well as their negligence on 'Other' redical inspirations apart from European philosophical tradition.

The second topic addresses the silence of Latin America within Critical Management Studies. The "Other" is the concept that articulates our own geopolitical place of enunciation. Through the revisitation of our radical philosophical tradition I engaged on a re-articulation of the notion of liberation as a normative proposition for the subsequent enlightenment on a local critical response before managerialist indoctrinations.

The third section approaches current Chilean management education as an empirical illustration of these previous debates that make sense about its own constitution, reproduction and im/ possible resistances through the contextualized selfunderstanding of its key actors (including myself in my double role of researcher and peripherical participant).

Finally, I devoted the fourth section to a reflection about discourse theory contribution to my work and, subsequently, to the emergent field of Latin American organizational research.

Methodologically speaking, my research has been conducted primarily by the application of an ethnographic strategy. This approach allows the articulation of Discourse Theory methodological inspirations particularly through the use of Glynos and Howarth's work (2007) well known as Logics of Critical Explanation.

\section{Critical Management Studies and Critical Management Education as Critical Articulators}

This research claims that Critical Management Studies (CMS) (Alvesson \& Willmott, 1992; Alvesson, Willmott, \& Bridgman, 2009; Grey \& Willmott, 2005) and Critical Management Education (CME)'s (French \& Grey, 1996; Reynolds \& Vince, 2007) lack of public contestation as well as neglected sources of inspiration different from Northern philosophies. Problematizing the dissent role of CMS and CME within this research, it has involved a discursive approach which aimed to unravel the meaning and practical scope of its critical endeavours.

Since 1992, CMS has deployed a fruitful debate among North American and European academic scholars attempting to contest the advanced capitalism within western societies problematizing its homogeneous, harmonic and teleological version of society. Nowadays, in their 'teens', and despite their apparent general agreement, Critical Management Studies is crossed by passionate disputes in an attempt to make its core meanings hegemonic. Targeting the so called 'mainstream management', CMS has posed its challenge in response to the wide expansion of management knowledge. Their critics are mainly oriented to the commercial logic and the positivist formulation of knowledge, which are hegemonizing the current management dissemination, while preventing alternative ways of conceiving organization and business. During its short academic history, CMS has been struggling with the formalization of its principles, in other words, attempting to define accurately what "critical" means within this context.

Two main streams have been formalized through publications, conferences and academic conversations, the European and the North American version of CMS, and both have set out their own understanding of critical 
management. The 'European' signifier attempts to capture and enhance its closeness with European Critical Thinking as their main source of inspiration. The Fournier and Grey's (2000) formulation developed a critical understanding built around three main threads: Reflexivity, Anti-performativity and De-naturalization as a degree of coherence among different critical statements. Their explicit intention was to formulate a series of remarks, which constitute a ground that aims to group a large variety of different theoretical and political positions in a flexible way, as well as define some boundaries, which separate CMS from mainstream, orthodox and managerialist positions (Grey, 2005). On the other hand, the CMS Division, the North American nomenclature for a section within The Academy of Management, has stated their principles through their explicit domain statement published in their web page ${ }^{1}$. Commenting this 'mission statement', Paul Adler (2002) delimited this definition as their understanding of the term "critical". He emphasized their openness to any critical view from a broad range of theoretical standpoints and no particular preferences for Critical Theory principles summarizing the 'spirit' of their statement as a "combination of left values and post-positivist methodologies".

In support to those who have stated that CMS shows an evident lack of impact among management practices (Grey, 2005; Parker, 2002), I have sustained that its claims remain captive within a particular western/northern academic arena, with little impact on different geopolitical scenarios. Based on Laclau and Mouffe (2004) I argue that the way in which CMS has stated their position has divided the ground of management in two contradictory camps, namely mainstream and critical ones, which finally is impeding a new articulation, which would politically contest the sedimented hegemony.

On the other hand, the internal disputes within CMS have revealed a logic of difference, which weakens these precarious antagonisms displacing

1 http://group.aomonline.org/cms/ the conflict between CMS and mainstream to the margins of the discourse. In an attempt to supersede these internal discussions Grey (2005) called for the development of just 'one voice'. In my opinion, this has trapped their endeavours within a totalization of the equivalential logic, which encapsulates these contradictory camps within an academic arena with no public impact as public contestation. Thus, their pluralities have been subsumed under a permanent search of agreement that has built frontiers which have been excluding meanings rather than subverting them.

My analysis suggests that certain signifiers or linguistic expressions like reflexivity, denaturalization, anti-performativity, and even critical management, work better, as names that substitute an absent fullness of a dislocated community. As such, they are metaphors with no corresponding facts - moments of naming in a radical sense- differently they strive to represent the failure of signifying system or language. Laclau calls these kinds of signifiers 'empty signifiers', an empty signifier is, strictly speaking, a signifier without signified (Laclau, 1996, p. 36). I proposed that CMS, instead of being regarded as an oppositional stance against orthodoxy in management, should be conceived as an empty signifier.

To recover plurality as a political stance in which competing meanings struggle for its hegemonization, I articulate that the antagonism between CMS and mainstream is not a struggle between positivities, but a subvertion game, that has never been achieved in all. Therefore, CMS as an empty signifier should be the place for a plurality of antagonisms that could go beyond sedimented and orthodoxical (northern) accounts of critiques and resistance. My proposition is that the very terms of 'critical' and 'resistance' should be always revisited within the understanding that there is no foundational knowledge, theoretical, cultural or political tradition that exhausts its themes. Within CMS, critical and resistance, has been constituted so far as a universal emancipatory need, but what is critical and what is resistance beyond this northern/western articulation of CMS remain in silence. 


\section{The Situation of Critical Management Education}

Critical Management Education, as a branch of CMS, has oriented its endeavours to state that management education, as a field, is far from an unproblematic practice. They aimed to challenge conventional understandings of management education (ME); to enhance the relationship between ME and social, historical and political aspects; to raise pedagogical concerns about contents and methods; to highlight the relationship of ME with management research and practice; and to explore its potential for critical and emancipatory thinking. Thus, management education is perceived as the place and the way in which critical orientations would challenge the hegemony of traditional management conceptions, and hopefully to achieve a considerable degree of political influence. All these theoretical and academic debates inspired my research, as management education is the case that I have explored during my endeavours.

My work attempted to point out the political significance of management education within the broader articulation of management as a practice. I suggest that management education, as part of management discourse, is a signifier which constitutes a particular structuring of work, schooling and political agenda of education relating to a bureaucratic and managerial conception of social reality. Following the insights of Discourse Theory, the work of Laclau and Mouffe (2004), I regard management education as a particular moment within certain discourses from which it acquires its identity. In other words, management education would lack a definitive foundation apart or previous to the particular discursive formation in which is taking place.

\section{Managerialist and educational/critical discourses of management education}

My approach considered management education as a contestable terrain shaped by the dispute of two different wider discourses which have antagonized its meaning, namely a managerialist and education$\mathrm{al} /$ critical discourse. Both formations are competing for hegemonizing meanings among management education identity and its practice.

The constitution of the managerialist approach is what makes the condition of possibility for the current and dominant practice of management education within western societies. Within the rationale of my research, the managerialist approach should be seen as an accomplishment that is, as a social construction, reflecting certain exercises of power. The key signifiers associated to a managerialist understanding of management education enhanced the role of management as a technical profession, management education as a vocational/ professional endeavour, and management faculty as vocationally oriented teachers and trainers (Bridgman, 2004). The rational, technical and scientific approach for management knowledge, management learning and management practice has been the way to sustain and develop social power. The latter means that management based upon expertise would be in the most effective position to define what the organizational situation requires, and provides an ethical basis for organizational authority.

Managerial and technical approaches to management education have been strongly contested by different positions, which seek to enhance the educational, and even the critical role that this practice should play. Those debates, which hold different approaches about what education should be, have been questioning the provision for vocational preparation of the workforce and the role of the higher education system in that task. This concern particularly affects business schools, which have been largely constituted as vocational sites. CME critics argue that mainly market rather than faculty has answered the question about relevance within business schools.

I drew on Thomas and Anthony (1996) accounts to address these concerns wondering about the educational side of management education. Their work suggested that education must involve knowledge and understanding and not simply the mastery of skills. More relevant, education should presuppose awareness of learners by being committed to an educational effort and a certain freedom of thought and action in its purposes. Thomas and 
Anthony's (1996) analysis stated that some strategies have been deployed in order to differentiate the work of a manager educator and the work of a manager. Relevant to my work was their insistence on focusing in what managers are, rather than the techniques that they would need in order to perform their work. Thus, the focus of an educational glance for business education would not be the practice of management, but the relationships of power, which they reveal (Thomas \& Anthony, 1996). The academics that are currently working within this particular stream look for contributing to an understanding of social relationships and power in organizations mainly inspired by critical theories and post modernism. Their work aims to challenge sedimented managerial approaches, and thus, opens space for what has been known as critical education.

In 2004, Grey and Mitev's polemic claimed for the necessary contestation to the instrumental and unquestioned teaching that sustains traditional managerialist management education. Critical reflection, the main nodal point of CME, has received the heritage of both critical pedagogy tradition and insights of Critical Theory (Perriton, 2004). The application of reflection to experience in order to challenge the hidden assumptions with the subsequent expectation of social transformation, intertwined with the 'conscious-raising' focus of a non-hierarchical relationship between teacher and student give sense and content to that nodal point. Thus, CME differentiated itself from 'banking model' of traditional management education where the reproduction of self-declared neutral and a-political contents hegemonizes the practice.

Moreover, CME has not been far from self-criticism raised from its very core proponents. I tackled in the case against critical reflection, as Perriton (2004) labelled it, which attempted to question its central role as the rationale and the method of CME as well as its short sights behind its selfdeclared unproblematic response to a problematic practice. In her terms, what has been neglected was the apparent necessity of an indoctrination process, which gave rise to the subsequent criticality; process that would be normally delivered within the 'banking' framework that this very practice is trying to destabilise. Elsewhere, Perriton and Reynolds (2004) challenged the limitations of traditional critical pedagogy embodied by CME due to its absence of reflexivity about the social dynamics of the classroom, especially in relation to the tutor role. Closely linked to this aspect is the universal aspiration of emancipatory attempts, which are presented as natural and widely consented propositions for democracy; in that way, it is that pretended universality, which sustains the insistence in configuring the manager as a 'victim' and the educator as their privileged 'emancipator'.

A re-visitation of those critiques from the rationale of Discourse Theory helped me in articulating management practice and management education as dislocated identities by the presence of antagonist discourses, in this particular case, critical discourses that are struggling to construct new nodal points and, therefore, new opportunities of identification for its subjects. I sustain that the role and challenges of the critical educator would be better understood within this dislocatory attempt, rather than just as an emancipatory ideal prosecution. In other words, I declare that critical educators are no privileged agents in charge of conscious rising in others, as a banking indoctrination in criticality would suggest; in my view, they are dislocated subjects endeavouring to re-centre their own contextual structure and their own identifications.

By drawing political frontiers, they are attempting to suture some floating signifiers, which no longer fit to hegemonized meanings. Consequently, I re-visited the universal pretension to emancipatory ideals within critical pedagogy. My contribution stated that the critical pedagogy monologue sustaining CME ideologically sutures radical possibilities for it, transforming that subvertion in a new form of indoctrination, which neglects the contingential feature of all social practices, and vanishes off the unevenness dimension essential to any dislocation. The predominance of a perennial logic of equivalence has divided the scope between managerialist and emancipatory approaches for management education, which has stimulated the presence of a fantasy in which the former, as 
internal enemy, would be blocking the identity of the latter, as well as it promises the arrival of a harmonic totality.

Finally, I have challenged Perriton and Reynolds' (2004) recast of Pedagogy of Emancipation to Pedagogy of Refusal. They used the metaphor of a 'colonizer who refuses', in order to grasp the widely disseminated feeling of being a purveyor of radical ideas within management, while taking a wage in return for legitimazing the managerial classes through education. For me the 'fourth wave' of critical management education that they proposed should not only encourage the plurality of theoretical rationale behind a diverse corpus of critical educators; but also, it should forefront the political involvement of a diverse corpus of agents within management education practices where management educators are just one more agent. In that way, 'the conflicted role of the CM educators in the colonizing structures of management' (Perriton \& Reynolds, 2004, p. 74) should consider re-positioning them(our)selves as (im)possible oppressed of both mainstream and critical traditions, thus, subjects of dislocation.

Hence, the critical educator is not the privileged agent of change any more; the real possibilities for social transformation would depend on the proliferation of multiple social change agents, multiple dislocations and multiple antagonisms. It is the very experience of dislocation of any critical educator, as over-determined experience, that could help to construct resistance. From here I would recast the Pedagogy of Refusal by the Pedagogy of Dislocation.

\section{Questions about our Own Place of Enunciation}

One of the main challenges of my research pointed out the need of new approaches for what has been regarded as a critical position within management studies. As I have said, CMS, and CME's considerations and theoretical inspirations are still mainly based on Eurocentric and North American philosophical points of view. Although their explicit concern about the silent voices within this social practice, the cultural, political and historical context of Latin America still claims for a specific consideration.

Latin-American thinking has had an exogenous and changing character strongly dependent on European and North American influences. The question about whether or not a proper Latin American philosophy exists has been the nodal point of L.A. Philosophy's debates. The argument has been constructed around the question of whether Latin America is developing its own productions or, on the contrary, they are just adapting foreign frameworks to analyze and make sense of its social and historical processes. Leopoldo Zea's (1989) assertion "we live in a world that already exists" implies to consider the very identity of Latin America, and its inhabitants, as a result of an external designation. Mignolo (2007) has asserted that America was never a continent to discover, but an invention forged during the process of European colonial history and the expansion of western ideas and institutions. Therefore, Latin America, as a name and as an identity, entails subordination as an ontological element of constitution.

As a contestation, our sub continental affairs have been raised by the 'liberation' utopia embedded in the Theology of Liberation (Gutiérrez, 1971), Psychology of Liberation (Martín-Baró, 1998), Pedagogy of Liberation (Freire, 2000) and the Philosophy of Liberation (Dussel, 1995). It is that concept of liberation, that crosses our local thinking, what concentrated my research endeavours deciding to focus my analysis on Paulo Freire and Enrique Dussel's major contributions due to its closeness with the main topics of my research, namely education and the wider understanding of Latin American self proposed identitiy. In that way, their work make possible to address liberation as an emancipatory ideal for Latin America, as cultural communities (further developed in Mandiola, 2010).

Paulo Freire was a Brazilian educator and an influential theorist of education. Paulo Freire's work was mainly devoted to the needs of the oppressed. He strongly believed that poor people through collective social action could liberate themselves from oppressive situations by changing the oppressive structures which generate in- 
equalities. Hence, his main challenge was to find a method where people could ground the above named collective social action (Rivera, 2004). This critical attitude would involve challenging certain meanings and certain argumentative strategies of dominant educational discourses and that, in doing so, these counter discourses would become the foundation of counter practices which challenged not only educational institutions, but hegemonic political structures. Enrique Dussel is an Argentinean philosopher, and one of the most relevant representatives of the Liberation Philosophy and the Latin American Philosophy. His concerns are focused on a liberating Latin America's philosophy for which the point of departure should be a radical critique of sedimented orthodoxical thinking systems. Dussel's meta-physics is developed with the intention of overcoming traditional understandings of ontology well disseminated among western philosophies. Different from these traditions, Dussel's meta-physics embraces the epiphany of who is beyond the self; it is about the unavoidable manifestation of the completely different "Other". Dussel states that by just accepting the disclosure of the "Other", the radical change could come, the change of the real liberation (Díaz, 2001).

Both authors share the emphasis on re-visit historical processes in order to identify the conditions of possibility for our current position as oppressed and, as a consequence, state that liberation is our way of articulating Latin American resistance. Their proposition can legitimately be understood as a response to the colonization problem for Latin American people. However, the initial formulation of a theoretical response to that issue may be in certain ways problematic for the purposes and framework of my work, which motivated my attempt to disclose their essentialist form of reasoning, as well as their ensnared in a reductionist framework. My aim of deconstruction in this regard was to clear any ambiguity or exclusion presented by liberation concepts as the chosen authors developed it.

Appealing to Laclau (2005) it was possible to argue that their conception of poor/oppressed is rooted in the limitation of the ontological tools available for political analysis in those times. As I have above-mentioned, both authors group under the name of 'oppressed' all Latin American poor people, which they homologated with marginal, peasant and low classes as synonymous. Oppressed are constituted against the 'oppressor', label that embodies the same foreign colonizers, wealthy people and local oligarchies. Liberation discourses so far, were strongly embedded within a dichotomy such as people versus oligarchy or oppressed versus oppressor. With Laclau (2005) I stated that these dichotomies imply a simplification of the political space, in other words, all social singularities tend to group themselves around one or the other poles of the dichotomy, assuming that labelled groups have a positive existence per se, a priori to any discoursive formation.

A traditional reading of liberation texts allows us to consider to regard the historical conditions of possibility of Latin American oppressed, as a 'natural' consequence of a colonizing determinist process, which shape the very identity of the poor. As well as a pretended closed identity, liberation's current conceptualization of oppressed implies a teleological definition of their aims, considering it as the fulfilment of the 'real humanization'. In that way, oppressed liberation movements have been relegated to a mere epiphenomenal level where the only things that could be problematized about are the social contents, class and the poor, which these oppressions express. Questions about the form of these 'liberations' became redundant meaning that any other political alternative has been excluded.

My statement is that not only poor people could be regarded as oppressed within current Latin America affairs, and particularly within the height of managerial discourses among our current social practices. Liberation attempts are still meaningful for our cultures, but a widening subvertion of their contents and forms appear necessary today. In other words, other forms of struggle may over determine its particular embodiment.

My analysis attempted to overcome the assumption that liberation was the sort of mobilization of an already constituted group, that is, as the expres- 
sion (epiphenomenon) of a social reality different from itself. Differently, I regarded the 'oppressed' as a relation between social agents where this very relationship constitutes them as a group. Far from an 'oppressed' identity, which was just the ideological expression of the a priori Latin American identity, 'oppressed' becomes a political category. It is not only another fact of social structure. The aim of my genealogy of liberation was the proposition of a new agency, out of a plurality of heterogeneous elements.

Within my analysis, oppression as the locus for the liberation claims, would exceed the frontier between peripheral poor marginalized and the foreign colonizer oppressor as such, involving new political frontiers which re-embrace oppression constituting it as a different sort of relationship between new social agents. I articulate liberation as a resistance response facing a new form of oppression within current Latin American affairs; or, in other words, a new form of colonization: the colonization through managerial discourses. Radicalizing the meaning of oppression formerly essentialized as the feature of the poor, I attempt to inscribe its very experience beyond the particularities of that social agent. Oppression, meaning the relationship that constitutes a Latin American colonized antagonized by a foreign (northern-western) colonizer, it is not only limited only by the poor identity claim.

Along with the main criticism raised by CMS, I argue that managerial discourse has colonized almost all spheres of our current way of life, constituting a precondition for an organized society, for social progress and economic growth. Mainstream managerial discourses, which offer the greatest wish of being part of the First World, push us to pursue its ideals, pretending that these ideals are ours, and pretending, as well, that we already have the tools to succeed, through hard work, in a society that is presented as essentially meritocratic. As its former predecessors, mainstream management invites us to 'act what others think' dangerously disguised as a neutral and democratic attempt, which presents itself as 'the end of the history'.

Within this new form of colonization, Latin Americans are still colonized, but what I want to enhance is a new form of oppression. This is the oppression of every single Latin American, which supports dominating discourses unaware of our own participation within reproductive practices. This 'new oppressed' is not the poor as usual, on the contrary, we are 'privileged Latin Americans' who have access to managerial education and privileged job positions. This is a marginalized position that 'failed' in identifying themselves as 'the other', co-opting with a logic that promises a success, which never arrives. We are marginal now not only because of our material poverty or our economical dependency, we are now oppressed due to our philosophical/theoretical poverty and our educational dependency. Both sorts of poverties are embedded in our reproduction and repetition of foreign contents, means and ends, part of this managerial ideology fully presented in our management education curriculum.

I explored the possibility of an oppressive relationship that constitutes a 'new other'. This new other shares with former ones a marginalized position in this world 'that already exists', but it is an "other" that has co-opted with the system that marginalized them. My 'new oppressed' is a large group of Latin Americans where I belong. All of us, educated within a foreign understanding of doing business, and consequently, organizing our social life; all of us, embracing management as a promise of development failing in recognizing our secondary position. My invitation here has been to construct this new other and from this understanding to build the path of our liberation.

\section{Pragmatist Victory? Chilean Management Education}

My analysis is focused on exploring what is supposed to be the objective reality of what management education in Chile is, and how it is organised and delivered. From the theoretical background of my research this endeavour meant to engage in a dialogue with this particular discursive formation in which different signifiers (management, education, critical, student, school of business, etc) were articulated in signified chains, which constituted these terms as obvious and evident objects (identi- 
ties) of a wider (social) reality that, in turn, posed what reality itself is. I put into question how the signifier 'management education' was articulated as a 'natural' embodiness of the new social order in Chile, particularly the unquestioned practice, which produces and reproduces the values that currently hegemonizes our societal life and supports our participation in the so called globalization.

As many scholars have stated, the political, economics and cultural changes that Pinochet's government imposed over our society could be regarded as revolutionary ones (Brunner, 1981; Drake \& Jaksic, 1999; Moulian, 2002; Tironi, 1985). Revolutionary because that experience transformed Chile into a particular phenomenon of neo-liberalism attempt, the so-called Chilean model (Drake \& Jacksic, 1999). By the end of the 1970's, people began to talk about the 'Chilean miracle'. The Chicago Boys' promised society was in place, which was strongly linked with the desire of accumulation and maximising economic gains. After the Dictatorship ended, the inauguration of the "democracy of consensus" in Chile never transgressed those values. One of the fundamental conditions of that democratic consensus was the autonomy of the economic sphere in order to protect itself from political contingent changes.

From their powerful positions at the military government, as well as the main Universities, and without any political opposition, the Chicago Boys set out to organize the country under their technocratic/managerial discourse and market principles embodied by a new power elite: expert managers (Imas, 2005). These market principles insisted on the right of private property, the non-interventionist nature of the state and the domination of market forces through privatisation and liberalisation of the economy. Hereafter, management education has been installed in Chile as a technical means to achieve that desirable social position. Furthermore, management education in Chile has not been problematized at all and is presented as the solution (or satisfaction) to a 'demand', which has emanated from the naturalization of the managerial discourse among Chilean organizations and society. I argued that this natural response is concreted through the 'importation and assimilation of MBAs' education, primarily from the USA, which is shaping our local delivery of postgraduate and undergraduate business education. Chilean management education constructed a stable system of objectivities, identities and meanings that appear as natural or inevitable based on the assumption that what the business school 'is' becomes common sense or taken-for-granted.

\section{Business Education in Chile, Reflections about Pragmatism, Consumerism, Individualism and Elitism}

The previous paragraphs addressed the issue that mainstream writings on management and faculty representatives have constructed on the problem of management education largely, in terms of adjusting and reforming their respective institutions to respond rationally and reasonably to the challenges within the constrains of the new regime in Chile. As a general scope here, management education is placed within the mainstream discourse of that practice. An understanding of the character and the role of higher education underpin this rationale in business, in relation to the wider institutional and structural contexts within which they function. From this perspective, their alignment with the wider political and socio-economic shifts associated with the developments of market economies and economic globalization is a necessary response. Those understandings suggest that the phenomena under consideration are governed by causal laws, implying that the changes are akin to natural processes beyond social and political control. Its main implication is the little questioning of the supposed inevitability and overpowering force of socio-economic development itself, and no room for alternative conceptions of the business higher education in neo-liberal societies. In this general context, an apparent issue has emerged concerning the lack of problematization of the status of business education. The social, political and fantasmatic logics approach of my research allows picking up and even developing this problem into a problematization: why 
scholars are collaborating, even sustaining the rationale and performances that they recognize to be problematic? Why aren't challenging dominant discourses apart from their personal and private complaining? Are there real possibilities for alternative frameworks within local management education? Contextualized self-interpretations are crucial in connecting this problematization to a range of related questions: Where did this regime of practices come from, and how and why has it been installed? Where is discontent among academics, why does this rarely translate into effective political resistance? How can I account for the way in which these embedded discourses have managed to grip subjects, especially when they are opposed to them? The following moment of my analysis involves identifying the relevant social, political and fantasmatic logics, which characterize the practice under investigation.

My involvement within business educational practice in Chile through my role of researcher allowed me to hypothesize the functioning of four social logics that might make sense and explain how its key actors, supporters and rebels, have their enjoyment implicated in a practice hegemonized by mainstream management dictates. The four logics of pragmatism, consumerism, individualism and elitism, developed here are informing the practices of the current management education in Chile (further developed in Mandiola \& Ascorra, 2010).

The underlying drive of the logic of pragmatism is to render all attempts measurable and functional, which in turn tend to feed and reinforce the logic of consumerism and individualism that shape the very nature of that practice, rendering academic activities into commodities deserving individual administration and profitability. Finally, logic of elitism draws a veil of exclusivity, which collaborates on reproducing embedded power privileges among its social actors.

The logic of pragmatism is evidenced, through the contextualized self-interpretations of its key actors, as a synonymous of utility and practicalness. These signifiers shape a practice which looks for rendering its deliveries on tangible success indi- cators for both, students and companies; the way students demand technical tools that facilitate their future professional practice and status achievement; and the way the market emphasizes quantitative indicators as result measures. The victory of pragmatism has rendered universities and business schools in private and competitive deliveries of technical tools to a demanding market of buyers of those 'practical equipment'. On the other hand, what this winning implies is the obscuring of the ideological constitution of that approach emphasizing it 'naturalness' and the lack of alternatives for counter positions. This impracticability is primarily located in wider structures, minimizing the impact of individual agency.

That pragmatism embedded within the wider logic of markets gives shape to the social actors' participation, articulating their relationships within the logic of consumerism. Having imposed a massive market reform for our higher educational mod$\mathrm{el}$, the former dictatorship government succeeded on establishing funds raising as a first priority privileging those 'academic' activities that could be offered as well paid 'products' to the market. The fees paid by university students became the key source of funding; as 'target group' they are nowadays its fundamental 'consumers', thus students subjectivities are colonized by their attributes as clients. Consumption increasingly becomes a passive experience; consumerism, not political involvement, is the best expression of personal freedom.

The social logic of individualism and elitism come to complete a picture in which that business education is articulated as a selective and competitive environment 'not for all'. Being positioned as a desirable attribute to compete and succeed within the professional market, business education is a practice that strongly contributes to maintain and reproduce social and class marginalization retaining the wider privileges on the hands of selected influential groups. By arguing that any achievement is the result of individual efforts, subjects become personally responsible for success or failure, by obscuring the social patterns that support and encourage success for just some and the failure for the majority. 
In this scenario, I invoke political and fantasmatic logics (Glynos \& Howarth, 2007) to highlight how various social logics have become operative in business school, both at the societal level and at the level of universities. For instance, the political logics of equivalence and difference can and have been deployed to draw frontiers between neo-liberal supporters and leftists advocators of a political approach for management, and to emphasize the similarities between pragmatism and business education. In that way, fantasies of success and failure, triumph and defeat among critics are also important since they offer some reasons to explain why it may be difficult to destabilize those established social logics. Once this assemblage of logics has managed to sediment itself firmly in the business academic arena, it should require complex counter-hegemonic work to experience something different and thus offer alternatives against what appears as inevitable and natural managerialist understanding.

Despite the fantasmatic logics surrounding business education that keep at bay political dimensions and obscures the radical contingency of social reality, dislocatory complaining has been operating only in the interstices of these official institutions. In other words, there are some traces of marginalized practices, which actively attempt to resist mainstream and deserve further consideration. Drew upon liberation rearticulation, my research attempts to propose a rationale that constitutes an oppressive relationship articulated from an abrupt and forced imposition of alien rationalities which have shaped and determined the identification of (im) possibilities of local depositaries. Thus, silencing, even erasing, our history these devices have subjugated its main local supporters pretending, on the contrary, their exaltation. In other words, a liberation attempt here aspires to de-centre the privileged identity of our local neo-liberal supporters stressing their points of differentiation with those who externally imposed that rationale (foreign managerialist); as well as establishing chain of equivalences with those who in turn they try to subjugate (local subjectivities). A local practice of CME should consider the contextualization of management history within the particularities of our history, highlighting its foreign origin, as well as the difficult implementation among our business practice.

I assume that social logic of pragmatism constitutes a dominant norm that is worthy of public contestation. Moreover, while it is true that the pragmatic dimension of this educational practice is at the forefront, it does not mean that the political dimension is necessarily totally foreclosed from view. Differently, there are some academics and students who constitute them and their skills in another way, envisioning themselves differently. The articulation of this research allows the projection, into my objects of study, a counter-logic of liberation in order to serve as a critical counterpoint to the belief that the logic of pragmatism is necessary and inevitable. I would like to affirm the idea of philosophical and political informed set of research and teaching practices that ought not to be homogenized in the name of just one model of business school. Again, our articulation of CME should focus not in the practice of business, but in the power relations that it reveals.

Meanwhile, counter-logics of liberation is still constructed loosely and abstractly, prescribing in this sense only a minimal normative content, it can still point to a Latin American philosophical tradition as a contextualized rationale for the alternative impulse in the self-interpretation of actors themselves. There are thuzs discursive resources available to people, even if minimally, to articulate their varied experiences of dislocation in an alternative normative direction. The counter-logics of liberation suggests the possibility to consider the 'outside' and 'otherness' as categories fabricated by the foreign hegemony stimulating the consideration of Latin America's image rescuing its own practices and ways of being from the imposed silence. These normative options could then receive support and open them up, via articulatory practice, to existing normative theories of local pluralism, democracy and justice. Practically speaking, the voice of the 'receivers' rather than the voice of 'delivers' should be exposed within our classrooms. 
Finally, the ethical aspect of critique is revealed here through the voices that intend to raise the historical conditions of (im)possibility of neo-liberal project for higher education, highlighting that this set of solutions was just one within others that were crushed by the dictatorship's powers. The counter logic of liberation, as a proposition, is a discursive tool that would allow the historical memory's recovery through the relevance of the geopolitical space as a place of enunciation. Before a discourse that is busy 'telling us how to do things', counterlogic of liberation seeks to articulate the need of 'listening' to the 'other', and particularly, to 'the other' that inhabits in us. Regarding critique, and particularly CMS and CME as empty signifiers, a Latin American radical standpoint could break the equivalence chain establishing a differential point within this resistance chain, and starts struggling for a place in the hegemonic never ending battle.

\section{Discourse Theory Contributions to/from this Research}

Retaking Perriton and Reynolds' (2004) proposition for a 'fourth wave' within Critical Management Education Studies, my research intended to contribute not only with a proposition in terms of a theoretical framework for illuminating resistance, but also with an original and stimulating paradigm to conceive the practice and its research.

The Discourse Theory, as it was developed by Laclau and Mouffe (2004) and other contributors, has been increasingly considered within organisation studies during recent years (Contu, 2002; Contu \& Willmott, 2003, 2006; Willmott, 2005). The new couple of political and organisational studies offer to management researchers an insightful framework, which allows a permanent subvertion of meanings and thus broadening the research agenda. Moreover, this framework is yet debuting and its contributions are still exploratory, therefore, my own endeavour expressed through this research has no other aim than to join those previous efforts in tasting its (im)possibilities. From a practical standpoint, my collaboration has been to assess its suitability to investigate discourses constitutions and its possibilities of counter positions.

This objective was supported by the assumption about the centrality of contingency as ontological standpoint which gives to the framework an openness that constitutes subjects as key actors within a history that attempts to be a less repetitive history (Laclau, 2000).

Despite its promising interventions and because its original lack of methodological stances, Discourse Theory received legitimate suspicions and doubts from both, supporters and rejecters in respect of its research scope. Its original advocators within organisation studies have been struggling to overcome the initial lack of concern that Laclau and Mouffe (2004) showed by methodological issues. Fortunately, the significant contribution of Glynos and Howarth (2007) came to bridge the methodological gap with a consistent, clear and well-supported approach that facilitated my work. Moreover, my research is still a new articulation of their proposition, which for sure yet owes to the masters. Despite these challenges I do believe that Discourse Theory offers something stimulating. It provides a radical rearticulation of hegemony and the universal which re-stimulate research from emancipatory ideals. More relevant, its developments come from its authors' radical reflections that are strongly informed for his Latin American backgrounds as an Argentinean philosopher and her activist experience during her time in Colombia, inputs that are inescapably modulating their voices of (apparent) first world intellectuals. Thus, my liberation attempt to recast CME rests not only in the Latin American philosophies that I exposed and re-articulated, but also in the very soul of my framework and methodological inspiration.

\section{Concluding: Tasks for the Future}

I have to mention that these 'conclusions' are far from being conclusive. Although I am trying to summarize, for my readers and for me, the main articulations of my work, I recognize that the debate that I intended to grasp has a long history and, of course, it does not pretend to be the final word. I 
hope I have moved forward on the challenging task of exposing our Latin American reality and in doing so, to stimulate further reflection and research.

The concerns that originated this research make me wonder about the current logics sustaining management education in Chile and its (im)possibilities for critical standpoints. To unravel the knit behind that question I re-visited the history of management practice and education globally and locally, as well as the recent developments of critical studies for both. Despite that apparent lack of critical considerations for our local implementation, the sole idea of mimicking again foreign intellectuals and utopian ideals does not make sense for an attempt that intend to challenge Northern/Western influences. Drawing upon Discourse Theory as a general theoretical and methodological framework, and exploring the possibilities of our own radical philosophical development I constructed an understanding of our management education short history, highlighting its inheritance of neo-liberal inspirations and proposing radical possibilities through the rehabilitation of a rearticulated notion of liberation.

Recovering the European and North American debates between mainstream and critical approaches to the study of management and its educational stance I explored the conditions of possibility for our current practice. Firmly embedded in our recent past, business practice and business education in Chile could be framed as the triumph of pragmatism as its supporters reported it. That pragmatism, articulated with logics of consumption, individualism and elitism had instituted a hegemonic voice that drastically silenced the pains of its imposition and its contradictions with local realities and needs. Despite its apparent closure and lack of critiques, the triumphalism discourse of pragmatism is widely crisscrossed by scepticism and refusal from those who dislocatorily and marginally participate in it. Those voices, yet loose and fragile resistant, constitute the subvertion embodiness and the condition of possibility for a new antagonism. My option to rehabilitate liberation philosophical tradition as an opportunity to articulate our Latin American radical counter position to mainstream management is in itself an attempt to listen to the voices that 'failed' against the triumphant pragmatism. Liberation was exactly the option that has not achieved to be, as Laclau has suggested dealing with. Furthermore, liberation is just one more attempt to fill the ever emptiness of critical approaches.

That normative suggestion for a local understanding of critical management studies is just a proposition, which aspires to guarantee enough consideration from local dissident voices to give way to a wider reflective process. Much more research and debate should be raised in order to install a fruitful discussion, with the need of putting at the forefront the political constitution of business education as a social practice in Latin America. This approach also requires a continual dialogue with those who sustain traditional conceptions of business, even if disagreements prove to be difficult or hard to overcome. More relevant, our Chilean experience should collaborate and enrich the work of few Latin American critical scholars who already have started a critical and local dialogue. This is an actual (im)possibility to overcome "siglos de colonialismo (español) que no en balde nos han hecho cobardes' in order to overcome 'nuestra nada de la historia universal'3.

\section{References}

Adler, P. (2002). Critical in the name of whom and what. Organization, 9(3), 387-395.

Alvesson, M., \& Willmott, H. (Eds.). (1992). Critical management studies. London: Sage.

Alvesson, M., Willmott, H., \& Bridgman, T. (Eds.). (2009). The Oxford handbook of critical management studies. Oxford: Oxford University Press.

Bridgman, T. N. (2004). Commercialising the academic's public role: Theorising the politics of identity constitution and practice in UK research-led business schools (Unpublished doctoral thesis). Judge Institute of Management Studies and Wolfson College, Cambridge, Cambridge University.

Brunner, J. J. (1981). La cultura autoritaria en Chile. Santiago: Flacso.

2 Silvio Rodríguez, Cuban singer, lyrics.

3 Fito Paez, Argentinean singer, lyrics. 
Contu, A. (2002). A political answer to question of struggles. Ephemera, 2(2), 160-174.

Contu, A., \& Willmott, H. (2003). Re-embedding situatedeness: The importance of power relations in learning theory. Organization Science, 14(3), 283-296.

Contu, A., \& Willmott, H. (2006). Studying practice: Situation talking about machines Organization Studies, 27(12), 1769-1782.

Díaz, G. (2001). Enrique Dussel en la filosofía latinoamericana y frente a la filosofía eurocéntrica. Tesis doctoral en Filosofía de la Cultura, la Ciencia y la Sociedad, Universidad de Valladolid, España.

Drake, P., \& Jaksic, I. (1999). El modelo chileno: democracia y desarrollo en los 90 . Santiago: LOM Ediciones.

Dussel, E. (1995). Introducción a la filosofía de la liberación. Bogotá: Editorial Nueva América.

Freire, P. (2000). Pedagogía del oprimido. México: Siglo XXI.

French, R., \& Grey, C. (Eds.). (1996). Rethinking management education. London: Sage.

Fournier, V., \& Grey, C. (2000). At the critical moment: Conditions and prospects for critical management studies. Human Relations, 53(1), 7-32.

Glynos, J., \& Howarth, D. (2007). Logics of critical explanation in social and political theory. London: Routledge.

Grey, C., \& Mitev, N. (2004). Management education: A polemic. In C. Grey \& E. Antonacopoulou (Eds.), Essential readings in management learning (pp. 151166). London: Sage.

Grey, C. (2005, July). Critical management studies: Towards a more mature politics. Paper presented at The 4th International Critical Management Studies Conference, Cambridge University, United Kingdom.

Grey, C., \& Willmott, H. (Eds.). (2005). Critical management studies: A reader. New York: Oxford University Press.

Gutiérrez, G. (1971). Teología de la liberación. Perspectivas. Salamanca: Ediciones Sígueme.

Imas, J. M. (2005). Rational darkness: Voicing the unheard in the modern management discourse in Chile. Administrative Theory E Praxis, 27(1), 111-133.

Laclau, E. (1996). Emancipations. London: Verso.
Laclau, E. (2000). Nuevas reflexiones sobre la revolución de nuestro tiempo. Buenos Aires: Nueva Visión.

Laclau, E. (2005). On populist reason. London: Verso.

Laclau, E., \& Mouffe, C. (2004). Hegemonía y estrategia socialista. Hacia una radicalización de la democracia. Buenos Aires: Fondo de Cultura Económica.

Mandiola, M. (2010). Latin America's critical management? A liberation genealogy. Critical Perspectives on International Business, 6(2-3), 162-176.

Mandiola, M., \& Ascorra, P. (2010). Chilean management education: Rhetoric of pragmatism, consumerism, individualism and elitism. Cuadernos EBAPE.BR, 8(2), 373-387.

Martín-Baró, I. (1998). Psicología de la liberación. Madrid: Trotta.

Mignolo, W. (2007). La idea de América Latina. Barcelona: Gedisa.

Moulian, T. (2002). Chile actual: anatomía de un mito. Santiago: LOM Ediciones.

Parker, M. (2002). Against management. Cambridge: Polity Press.

Perriton, L. (2004). A reflection of what exactly? Questioning the use of 'critical reflection' in critical management education. In M. Reynolds \& R. Vince (Eds.), Organizing reflection (pp. 126-141). Hampshire, UK: Ashgate Publishing Limited.

Perriton, L., \& Reynolds, M. (2004). Critical management education: From pedagogy of possibility to pedagogy of refusal. Management Learning, 35(1), 61-77.

Reynolds, M., \& Vince, R. (Eds.). (2007). The handbook of experiential learning $\mathcal{E}$ management education. Oxford: Oxford University Press.

Thomas, A. B., \& Anthony, P. D. (1996). Can management education be educational? In R. French \& C. Grey (Eds.), Rethinking management education (pp. 17-35). London: Sage.

Tironi, E. (1985). El Régimen autoritario. Santiago: Dolmen Ediciones.

Willmott, H. (2005). Theorising contemporary control: Some postructuralist responses to some critical realist. Organization, 12(5), 747-780.

Zea, L. (1989). La filosofía americana como filosofía sin más. México: Siglo XXI. 